\title{
The Necessity for the Compilation of a Naval Staff History
}

\section{Captain Alfred Dewar (Retired), B.Litt.(Oxon) O.B.E., R.N.}

To cite this article: Captain Alfred Dewar (Retired), B.Litt.(Oxon) O.B.E., R.N. (1921) The Necessity for the Compilation of a Naval Staff History, Royal United Services Institution. Journal, 66:463, 369-384, DOI: 10.1080/03071842109434616

To link to this article: http://dx.doi.org/10.1080/03071842109434616

册 Published online: 12 Nov 2009.

Submit your article to this journal $₫$

Џ Article views: 10

Q View related articles 두 


\section{THE JOURNAL of twe}

\section{Royal United Service Institution.}

Vor. LXVI.

AUGUST, 1921.

No. 463.

[Authors alone are responsible for the contents of their resfective Papers. All communica. tions (except those for perueal by the Editor oaly) should be addreased to the Secretary, Royal United Service Institution.]

\section{THE NECESSITY FOR THE COMPILATION OF A NAVAL STAFF HISTORY.}

By Captain Alfred Dewar, O.B.E., R.N. (Retired), B. Litt. (Oxon).

On Wednesday, I6th March, 1921, at 5.30 p.m.

Admiral Sir F. C. Doveton SturdeE, Bart., G.C.B., .K.C.M.G., C.V.O., LL.D., in the Chair.

Tue. Charmax: Ladies and Gentlemen, Captain Alfred Dewar has kindly consented to come and give a lecture here on "The Necessity for the Compilation of a Naval Staff History." He requires no introduction from me because he is a Gold Medallist of the Institution and he is well known for his historical work. IVith your permission, I will now. ask him to commence the lecture.

\section{LECTURE.}

ADMIRAL VESEY HAMILTON has a very illuminative remark in the preface to his work on Naval Administration. He said : "For myself I have learnt more of the interior workings of the Admiralty in the compilation of this volume than I did in five years at the Adniralty where the work in one's. own department is more than sufficient for the day." This gives a very clear conception of the value of history and of its direct relationship to business. Unfortunately our 
introduction to the subject usually consists of the dry bones of something that happened a hundred years ago, whereas what we want and what is of real and superlative use to us is a history of events in the last ten or twenty years.

It is a great mistake to think that history is concerned with the faroff past; it is just as directly concerned with the immediate past and with the affairs of last month. These may appear to be the concern of current business, but business must be measured in terms of relativity and not merely of time. Some crucial point of to-day's business may depend on the wording of a contract or of a will drawn up many years ago and never looked at since. The real difference between current business and history is that the man dealing with current business is dealing with emergencies as they arise. The daily tide of paper covers his desk in the morning and ebbs away at night, leaving him no time for thought or necessary research. As Kempenfeldt, writing to Middleton in 1779, said: "We are every day plagued and puzzled with minutix whilst essentials are totally neglected."

Where then does the function of history come in? Its function is to stand aside from current business and give a clear exposition of events. This may seem quite a simple matter, but it is not so simple as it looks. It may appear to be merely a question of sending for former papers and examining them for ourselves. But, first of all, if there is no history one doesn't know what the papers are. You may know those of last week and last month and the Secretary's Records may produce them for a year or two back, but that is a different thing from knowing them and having a clear and comprehensive grasp of all the ins and outs of a subject for thirty or a hundred ycars back. Take the subject of Naval Education, for instance. You know there was a considerable controversy about it some fifteen years ago. Now its cardinal problem is to adjust naval training to the demands of a growing number of technical sciences. That problem began in 1860, and the fact that no one has ever been encouraged to writc a history of Naval Education gives a curious insight into the naval mind. Numerous committees have sat on it-the Shadwell in 1870 , the Rice in 1885, the Tracey in 1901, the Douglas in 1905, the Custance in 1912, the Goodenough Fleet Committee and Lord Jellicoe in 1918, and they all deal to a large extent with the same problems, but they have never been digested and reduced to the form of a history.

There is another reason why history is of special importance to the Navy. The Navy is a business which is only occasionally actually engaged in the performance of its business, and its business is of such a nature that the people doing it often do not know what they are doing in its relationship to the whole. This they can only learn from history.

But it is not only after the war but equally during the war that historical method is a great asset. One of the greatest difficulties one has to face in the work of a great staff is the difficulty of obtaining in a brief and handy form what has been said, done, or decided on some important point, such as the possibilities of invasion, or an expedition to the coast of Syria, or the mining of Heligoland Bight. 
The papers are here, there or somewhere, but without something in the form of an historical summary it is difficult for anyone new to a big office to get hold of the right ones.

During the War there was no effort made to compile a clear brief history of German submarine warfare, with the result that all sorts of fallacious ideas passed into current thought. For instance, at Dover it was thought that the Belgian coast barrage had a great effect on German submarines, but no one really conversant with the history of the subject ever thought so. At the very time, in the summer of 1916 , when the Vice-Admiral at Dover was congratulating himself on the absence of mines in that area, Flanders submarines were still active on the East Coast.

Now it may be argued that this is not history but really the dissemination of intelligence, but history is merely a form of publicity and communication, and so far as the collection of material is concerned is not unlike intelligence work.

During the War one often felt very acutely the want of a provisional history of what had been done during the early years of the War. A very striking instance of this is to be found in the recently published Jutland papers. ${ }^{2}$ Admiral Jellicoe, in an important letter dated 3oth October, 1914, asked for the Harwich destroyers to be sent to him when an action was imminent and his letter received the general approval of Their Lordships. But when the action was imminent we know that the Harwich destroyers were not sent, and it is probable that the letter and its history had been forgotten.

As an instance of the advantages of a provisional history may be cited the case of a short report on German Submarine Tracks which was prepared in 1917, and which indicated that for nearly a month they had been going up the same track in the North Sea about twentyfive miles wide. Plans Division immediately prepared an operation on this track involving the use of two flotillas of the Grand Fleet, half a flotilla of submarines and a minefield, which led to the destruction of three submarines between 2nd and 8th October ( $U$ I06, $U$ 66, and U 50). But the Grand Fleet was never told the history of this. The information was regarded as too secret for general dissemination. Their destroyers had experienced very heavy weather; they had scen nothing and the Grand Fleet was opposed to further operations of the same sort, though they might have been repeated on at least one occasion.

In any case this is an instance of the value of publicity and intercommunication which is the real working principle of history. All sorts of work was being done in all quarters of the globe, great divisions had sprung up almost in a night, the capacities and limitations of the mine and submarine had to be gauged, and the general

1 The cessation of German submarine activity in the summer of 1916 was due to an order issued by Admiral Scheer, C.-in-C. of the High Sea Fleet, on $24^{\text {th }}$ April to ccase operations against commerce. Flanders followed suit, and with the exception of an occasional mine-laying trip on the East coast and one or two trips to the Channel, submarine activity ceased till September, 1916.

2 "Battle of Jutland," Cd. 1068, 1920, page 60r. 
ignorance that prevailed about one another's work was a serious hindrance to the prosecution of the War. Up to the end of the War many naval officers remained ignorant of the real machinery of the blockade. All sorts of points cropped up where history was.required, such as the history of what had been done to stop the Lulea iron ore trade and to mine the Bight, and it often took a long time to get a sufficiency of information about a subject because no history of the matter had been kept. Again, when the question of convoy was being considered, distinguished officers who opposed it had failed to grasp the fact that it had already been performed successfully in the Indian Occan in bringing home the Dominion troops, and the history of the early convoys supplied sufficient answer to many of the objections urged against it.

The best systems of registry and indexing cannot take the place of a history, for history does not merely index, but digests papers and reduces them to a manageable form. This is the business of history, and it is also the secret of successful business. Those sections and divisions which had the history of their work and its figures at their fingers' ends were able to make rapid decisions for any sudden emergency. There is no time in such circumstances to digest a inountain of papers. Therefore, behind the worker in current affairs there should stand the historian, for history and historical research is really an effort to throw light on the real state of affairs. It is an endenvour to find the truth, and how difficult it is to find the truth, especially for men in great place, is too well known to require mention. But though history is important and the Navy is important, it is a fact that the two in combination are considered by many officers of the Navy as of very little importance.

Before dealing with the compilation of a Staff History, it is desirable to say a few words on the principles of historical method ${ }^{2}$ and the organization of historical work.

For the principal aspects of historical work Bernheim's headings may be accepted. They are briefly-

(a) Heuristics or the finding of the sources.

(b) Criticism or the criticism of sources and corroboration of their statements.

(c) Interpretation or establishment of their casual connections,

(d) Arrangement and expression.

These headings may appear to a general audience somewhat academic but they are very sound.

History is the record of men's doings and at first is only to be found in documents. We are so accustomed to taking books down from shelves that we forget that at first there are no books. There are only vast piles of papers and one does not even know what they are. It is like searching for the hidden word of Masonry. I have been told that the Frecmason is supposed to go to Jerusalem for the purpose.

i For historical method sce "Historische Methode," by Ernst Bernheim, and tho shorter work of Langlois and Scignobos. For principles of archival work sec "Manuel pour le classement des Archives," Dr. S. Muller, Feith and Fruin, 19ro. 
But if he merely wishes to learn its difficulty he need not leave Whitehall. The preliminary work of history is to get the documents. To know if there are any, what they are, and where they are, this is called by Bernheim "Ieuristics." If you have ever tried it, you will feel sure that it deserves to be called something.

What Bernheim calls Heuristics, or the discovery of sources, is closely associated with archival work-that is the custody and cataloguing of sources. Till the sources are discovered and properly arranged it is-extremely difficult to make any real progress. But to arrange them postulates a general knowledge of the War, and therefore a sort of preliminary survey of the War is required in order to gain a correct perspective. One of the principles of archival work is that any particular collection such as the papers of a particular department or section should remain as a complete whole, and this has not always been carried out. Now the Admiralty has a department-the Secretary's Record Office-to deal with papers, and its general system is sound. The headings with which it worked are to be found in a digest table which goes back to about 1782 (the copy I have seen has Barrow's name on it), and this is really a List of Subject Headings. This was kept annually, and a Compendiun of Digests, covering a longer period of about thirty years, lept a record of the more important subjects. Unfortunately the Digest Table and its system gradually came to refiect the general trend of naval thought.. It was used chicfly for looking up questions of personnel and not for general historical study, so that the War found it lacking in a number of headings required in modern war. Generally speaking, it had come to deal rather with what would be termed in modern staff parlance "administrative" work. At the same time the general arrangement in commands is sound and is very old and the whole system only required spice and general adaptation to modern needs. One very grave defect was that Confidential and Operational papers were not given to it, but were kept in safes. I shall forbear to say anything about safes. I believe they are useful as a safeguard against burglars, but for archival and historical purposes their utility is less evident.

I shall say no more of Heuristics. It is an important branch of historical work and gives rise to all the mixed feelings of a quest. You may be talking about some subject with someone and he may say "I believe I have a paper about that," and will then produce, perhaps from a safe, the very paper or bundle of papers which constitute the key to the subject. You will gaze at him, and you will understand how Balaam felt when he was uncertain whether to bless or curse.

Now when the War had started no one thought of history.' No one thought the history of what happened in 1914 would be of any value in 1916. There was no thought of a provisional history of the War year by year or of a Staff History. History was a mere Cinderella whom

1 Admiral Sir Doveton Sturdec corrected this statenent and pointed out that Sir Julian Corbett and Admiral Sir Elmund Slade were asked to undertake this work as soon as the War commenced, but the fact remairis that in 1917 there was no provisional history of what had happened in 1916. Such a history could only have been compiled by the sections concerned. 
Sir Julian Corbett fortunately offered to adopt, and she went over to the C.I.D. She is still there, and she was so badly treated in her real home that she may not be very willing to come back. There she took the form of what used to be termed the Interim History, which was intended to be a history for popular consumption to be ready by the end of the War. It was quickly found, however, that before you use records stow'age must be found for them and they have to be bound and put in boxes, and this led to the institution of what is really an Archival Section. which, though attached to the C.I.D., is really an extension and annexe of the Secretary's Department.

History must always be closely in touch with and may even be regarded as a function of the Secretariat, for it arises directly out of records which are the special charge of the Secretariat. This work is being slowly but surely done and is the first stage of a Naval Staff History. One is sometimes inclined to think that too much importance was given to the idea of a popular history, and that principles of staff work were subordinated to the unique competency and literary reputation of Sir Julian Corbett. 'The primary idea seems to have been the compilation of a popular history; the archival work was regarded merely as a subsidiary issue, whereas it is the converse that is true; it is the archival work that is of real importance; once that is done, you can write as many histories, in as many forms, as you like. This principle comes out very clearly in the German Admiralty Staff History, which is issued by the Superintendent of the Marine Archives, who is a vice-admiral. However, the main end was secured. The papers began to be arranged and continue to be arranged under competent supervision.

At the snme time Sir Julian Corbett's History is not a Staff History, nor is it official in the sense of being an Admiralty official history. In fact the Admiralty have been careful to attach a disclaimer to its volumes emphasizing the fact that they are not responsible either for the substance or its presentation. They have merely given Sir Julian Corbett access to their records. As a measure of expediency arguments can be found in favour of such a system. No one else would or could do the work, and a large measure of gratitude is due to Sir Julian Corbett for undertaking it. But to divorce historical work from the Naval Staff and, so to spenk, to " farm "' .it out (however competent may be the historian) is unsound, for history is not an end in itself but only as an aid to work in the present and cannot really be understood and utilized except by those who are practical exponents of the work.

The fact remains that there was no historical section of the Naval Staff of the Admiralty and the C.I.D. undertook the work and the system has proved workable, and so long as the necessity of a Naval Staff History is borne in mind, the archival work done by the C.I.D. for the Admiralty and the historical work done there will be of great use to the Naval Staff. How then does it differ from a Staff History?

A Staff History is an intensive study of the general and detailed aspects of the War. Its name implies that it must be prepared by a Naval Staff. If the Naval Staff cannot undertake it, it cannot be done 
at all. It differs from the history being prepared by the C.I.D. in certain essential features :

(a) Its scope is wider and more exclusively technical. Its aim first of all is wider. It embraces all sorts of subjects outside the scope of a popular history that. can only be satisfactorily dealt with from a naval point of view. For instance, in operations such as the Falklands operations, the methods of coaling and supply, and the considerations that led to the choice of different anchorages. In covering this ground it will often be very uninteresting to anyone but a naval officer, just as a detailed history of cotton spinning will be uninteresting to anyone outside the cotton industry.

(b) It must be documented. For instance, the naval officer will not be content with opinions but will wish to read for himself the text of important signals and orders. In studying the disposition of squadrons and flotillas he will require the actual text of the operation orders on points where any doubt occurs.

(c) It must be written from a definitely naval outlook. Here, in order to free myself from the possible. reproach of bias, I shall quote the historian. Sir Julian Corbett says in his "Introduction to the Campaign of Trafalgar": "The campaign has been left in the same comparative darkness that enshrines the bulk of our naval history. It is not an exaggeration to say that the whole of naval history requires rewriting on staff lines. The need for a Historical Section at the Admiralty is crying. If you sever the work from the Admiralty you sever it from the well-spring of that intangible spirit which is our peculiar asset. Nowhere out of intimate touch with the Fleet can its inspiration be assured. No chair of history can fill the place of an Historical Section. What is of the sea must breathe the breath of the sea. Without it we pine in academical speculation."

Briefly, if you want to write on shoemaking for shoemakers, you have to be a shoemaker. Another historian-one of the most distinguished in Furope-Ernst Bernheim, deals with the subject more generally in his "Lehrbuch der Historischen Methode." He says that one can rightly formulate the question whether the handling of single branches of history belongs to the sphere of the historian and is not rather the businesss of the respective craftsmen. Assuming that you can find a "Fachmann" with some historical education, he holds him to be much the most competent for the historical handling of a subject. The professional man will consider its development from the standpoint of the professional. What is of interest to him will not arouse the interest of historians and is by them passed over or insufficiently explained.

(d) Fourthly, it must be in close touch with practical experience and current naval thought. This association cannot be obtained outside the Admiralty. Otherwis: it becomes separate from the revivifying stream of actual current thought. We have given reasons why naval history should be written by a Naval Staff. There is another reciprocal advantage to be gained. There is a renson why Naval Staff officers should 
write or try to write history. It is an education in itself. The natural tendency is to accept the printed word or the typed lecture. But here there is nothing-nothing but a virgin soil of documents. In going through them the worker will discover all the actual channels of business, will see the actual working of the machinery, will hear its creaking, will tread in the actual track of the men who performed the work and get in touch with their immediate difficulties. 'That is why Moltke attaclied such importance to staff officers working for a year in the historical section of the Gross Generalstab. It is not the printed book that alone is valuable. The process of its compilation is still more valuable. And there is a great deal that has to be left out of the book that is valuable. Some of the most important parts of a book never get into print. Work of this kind is a valuable training for intelligence work, for in both cases one is confronted with reports, some conflicting, some absurd, many incorrect, a few directly contradictory-all to be collated into a picture of the course of events. Therefore not only should a Naval Staff History be written by the Naval Staff, but Naval Staff officers who have any talent in this direction should all for a season be set to compile history. If this work is done outside the Navy, its fruits do not return into the current of naval thought.

There are four principal auxiliary sciences which are required for the historian-language, script, knowledge of documents (diplomatik), and geography. The two first, language and script, can be dispensed with, for the language is English and the script is usually typescript. Knowledge of documents, such as logs and signal logs, the naval officer has, for he has kept them since he was a boy. Naval geography requires a good knowledge of navigation, and this, too, is part of the ordinary equipment of a naval officer. Literary talent is more difficult to acquire, but there are a number of officers who possess it.? I shall now say a few words on principles of arrangement.

In the history of the Russo-Japanese War an attempt was made to deal with events in chronological succession and to enbrace events in all theatres of operations, whether naval or military, in one progressive narrative. The aim was to give a clear impression of the interrelation of the various incidents, and of the resultant decisions. It is the system of sceing everywhere at the same moment, and though something of the same sort has been attempted in the C.I.D. history, it is only possible to a limited extent.

The fact is it is not real. No one at the Admiralty or at sea saw everything that was happening in every theatre of the War. The big events certainly reacted on one another, and where they did so they were linked up, and can be linked up in history, but they must be dealt with separately.

Again, there is a great advantage in working along the lines on which business was actually conducted. A preliminary study of the

1 One of the great bars to historical research, probably to all kinds of research, in a large disciplinary community like the Navy, is the fallacy of general competency, that is, that everybody is equally competent to do anything. There are a number of young officers with a literary and historical talent, but it is very difficult to obtain their services. 
War usually indicates the main lines of treatment. It is not possible to state them categorically. Sometimes they are by commands such as the Grand Fleet, sometimes by incidents and areas such as the Dardanelles; sometimes by topics such as anti-submarine operations, or convoy.

It is necessary, of course, to show when and how the operations in different areas were mutually affected, but not only is it better to keep them distinct, but if they are treated in detail it becomes a matter of necessity. The best method of approach is probably by means of monographs. The Historical Section of the Training and Staff Duties Division is busy with this work and has already completed nearly a score of them, all of which will be useful in the compilation of a Staff History, and do in fact constitute the beginnings of a Staff History.

The following is a very rough outline of a Staff History :-

General History.

I. Forces, Mobilization, Plans and Policy.

2. Home Waters in 1914 .

3. Flanders Coast.

4. Operations, Foreign 1914, Issingtau, Cameroons.

5. Protection of Trade, culminating with the Battle of the Falkland Islands and Destruction of Dresden and Königsberg. l'acific, East Indies, Atlantic.

6. Home Waters, 1915.

7. The Dardanelles.

8. Development of Patrol Flotillas, Growth of Mincsweeping, Routes and Escorts.

9. Naval Work of Blockade.

10. Home Waters, 1916-Battle of Jutland.

II. Submarine Warfare, 1917 and 1918.

12. River Expeditions-Mesopotamia and Archangel.

13. Home WVaters, 1917 and 1918.

14. The Admiralty and Naval Staff.

Then there are a series of special histories required on operational and technical subjects, such as Fleet Tactics, Convoy, Bombardnents, Landing Operations, River Work, Minesweeping, Minelaying, Gunnery and Ordnance, Torpedoes, Hydrography, Aircraft in Naval Work, Submarine IVork, Coastal Motor Boat Work, Naval Construction, Naval Hygiene and Medicine, Administration, Dockyards and Repairs, Administration of Stores, of Coal and Fuel, Organization of Temporary Bases, Welfare, Canteen and Recreation.

A few words may be said as to other Staff Histories. It is hardly necessary to emphasize the importance placed by Moltke and Foch on history. The whole doctrine of war in Germany and France has been built up on historical analysis. Foch was an ardent advocate of historical research. The French Naval Staff has instituted a Historical Section with four bureaus by a decree of 19th July, 1919, installed at the Avenue Octave Gerard. Its object is to furnish the French Navy with a precise documentation (documentation précise) of the War 
drawn up in rigorous style. It is under Captain Castex and has members of the famous Ecole des Chartes attached to it. A historical section was previously established as early as Igro in the French Navy, but it was merely a section of an Operations Division and was quickly absorbed in researches on current work.

In Germany the Admiralstab are at work preparing a history under the Superintendent of the Marine Archives. It is in five sections-The War in the North Sea; The War in the Baltic; Black Sea; Cruiser Warfare; Submarine Warfare. One volume has appeared, the first volume of the first section. ${ }^{1}$

It is hardly necessary to mention the older histories. The German Staff History of the 1870 War appeared between 1874 and $188 \mathrm{I}$. It was in five volumes, with five cases of maps, uncritical and laudatory. Then there is the immense work of the American Civil TVar, seventy volumes, 1880-1901, merely a compilation of documents-not an example to be followed. Then there is the French General Staff History of 1870 which began in 1901, and is still incomplete.

We should avoid bulk. Detail and documents are required but they should be carefully selected. The best form for the Staff History would probably consist of a series of revised monographs after the style of those issued by the German Great General Staff, with one good introduction of about 100,000 words giving the main aspects of the War.

At the same time one may well conclude with a note of warning. There is always a tendency to seize on catchwords. IVe do not want history to become a catchword.

"Practical" was the great catchword of that most unpractical Navy, the navy of the eighties and nineties. When I was a midshipman there was great loud talk of being practical, and masts and yards were supposed to be very practical, and in order to be practical we had to sit in gunrooms and learn off by heart how to tack and wear ship.

We do not want to turn history into a subject for examination. History is a necessity to the Navy but not to each individual naval officer. One hears sometimes of the two schools of historical thought and material thought. But the fact that history is of importance does not make gunnery unimportant, for gunnery cannot easily be dissociated from naval history. Whe do not want to add another subject for examination and to set naval officers to learn up naval history. To turn history into a subject is to kill it. Dr. Schiller tells us that experience show's that institutions once set up to realize a purpose tend to operate so as to defeat the purpose to which they owe their being. Every : institution generates toxic by-products and waste products and in the end is choked by them. As William James said: "The natural enemy of a subject is the professor thereof." We want to be very careful then that our conception of history is real and practical and that our methods of study are correct.

1 The first volume of the Baltic series has also been issucd.

2 Hibbert Journal, October, 1920. 


\section{DISCUSSION.}

Cartain T. Danneuther, R.N.: Mr. Chairman, I.adics and Gentlemen, the subject with which the lecturer has dealt now comes within the province of the Historical Section of the Naval Staff under the direction of the Director of Training and Staff Duties, Admiralty. Formerly historical work was undertaken by the Naval Intelligence Division, with which I am connected, and I should like to give the direction in which that latter department worked.

It was the practice for the N.I.D. to collect all reliable reports from naval officers or eye-uitnesses and issue them in narrative form to the Flect as soon as possible, without criticism. These volumes, when completed, were put away for ten years, and may be said to correspond to the confidential Naval Staff monographis now being written in narrative form from official documents. The final result of this process is to produce a short history of naval operations, written from the original reports, preferably by a naval officer and a historian in collaboration, as, for example, Admiral Sir Edmund Slade and Sir Julian Corbett. Such a history is necessarily technical and confidential, because it deals with the class of matters to which the lecturer has referred, but it is also written in a critical style with all the facts from both belligerents available. I would submit that it is desirable to wait ten years before the Staff monographs can be considered fit for the production of a Naval Staff History for the Navy. The reason for this is that monographs are a pure record from British sources of the actual events as they occurred. They are merely documents in narrative form, and it is considered improper to produce a history criticizing the action of officers whilst such officers still hold important commands in the Fleet. $\Lambda$ n interval of ten years is sufficient to clear the board of those officers, as far as it affects discipline, and it allows of ten years, too, for digesting the cnemy side of the question. If a staff history were written now of the late War it Hould possess the fault that the whole of the German case cannot be appreciated. $\Lambda$ the present moment the Germans are waiting for the production of Sir Julian Corbett's work, and, no doubt, Sir Julian Corbett is anxious to see the German official history. Both works show a want of appreciation of what was done by the other side. In ten years' time, uhen Sir Julian Corbett's history is out and the German history is available, it will be time enough, in my opinion, for the Naval Staff itself to produce a critical history of the operations, when a full knowledge of the view's of both sides of the question is available.

$\Lambda$ point connected with the production of such a history which has not been dealt with by the lecturcr is a consideration of the use that naval officers can make of it for study when it is written. I am sorry to say that the confidential work of Admiral Slade and Sir Julian Corbett is not sufficiently appreciated in the Service, if one can judge by the numbers that have read it. I submit to the lecturer for his opinion a scheme for the production of a staff history. In my. view you want a historian to produce a vignette of the times in which the campaign takes place. You want to put into the reader's minds the Admiral's own temperament, and that of his adversaries, and what his Government thought about him, and what actions were expected of him. You want to state actually what the Idmiral knew and all the surrounding circumstances, so that you can then close the book down and allow the student or class of officers to suggest a line of action to be taken in the said circumstances. In cffect; you say to the officers, " Here are the circumstances: if you vere in. that man's shoes what would you do?" If the class think the problem out and express their opinions on paper, they would learn a historical lesson by referring again to the next chapter of the history in the same way as a schoolboy gets the answer to an arithmetical 
problem from the key, and learn what the adniral actually did, to compare with their own opinion of what he should have done, and it can then be decided whether the officers' opinion or the admiral's action was the better. They would then find out whether the admiral made mistakes at the time and the influence they had on the campaign later, or whether their own ideas were mistaken and how they would have norked out in the light of subsequent events.

I hope the Naval Staff History will develop from the monographs so as to give the actual circumstances of the time in set problems so that officers can be told "Here is the case, work it out for yourselves and say uhat the admiral should do."

Cartain Thursfielv : I would like to protest against the view just expressed by Captain Dannreuther that 2 ten-year interval should be allowed to elapse before a Naval Staff Ilistory is written. The grounds, I gathered, for that view were that the full materials are not available. That is perfectly true, but full materials never are availuble. There are aluays materiats at hand and they are always increasing as more and more information comes to light; and if we wait for the full materials to be available the history will never be written at all. Anyone who has had the job of wirting history, even in a small way, and discovering exactly what happened in any circumstances, know's how very difficult it is to get a clear idea as to what happened if there has been any appreciable delay before the task is undertaken. One of the most reliable sources of information is the pcople who pere present at the events one is trying to narrate, and the sooner after those crents one can obtain their narratives the more accurate and the fuller will they be. If we put off the compilation of the history we lose in accuracy. Again, there are important lessons to be learned from what happened in the late IVar, and I do not think we should be condenned to wait for ten years before being allowed to endeavour to learn those lessons.

I would lilie to support the lecturer's view of the necessity for a Staff Llistory. Sir. Julian Corbett's history, excellent though it is, does not altogether fulfil the needs of those who are trying to learn lessons from the IVar, principally because no authorities are quoted. The preamble to that history states that the Lords of the Admiralty have given Sir Julian Corbett access to official documents, but it does not state that they have given him access to all official documents. In any case Sir Julian Corbett docs not quote any official documents, nor does he even give in all cases a hint as to how much he has taken directly from official documents and how much is the result of his own deductions from such documents as he has had. I suppose that is one of the chief reasons why the Admiralty specifically state that they take no responsibility for his presentation of the facts. It is almost impossible that they should. Sir Julian Corbett undertook the business of producing the history early in the War. The Board of the Admiralty which entrusted that work to him might have been prepared to accept his presentation as expressing their view's, but obviously they could not bind every subsequent Board of the Admiralty to do so. The result is that Sir Julian Corbett's history is much more a popular history than an authoritative one, and that is the reason why a Naval Staf History, which probably would not be so good in many ways as Sir Julian Corbett's, but would have the advantage of being authoritativo and quoting sources, is so much required:

Instructor-Commander Tuck: As I have been connected with the production of Sir Julian Corbett's historj, and as 1 am at present in charge of the production of the Naval Staf monographs, perhaps it may be of interest if I make a few remarks. It has always been felt that there would be a difficulty of distinguishing 
what are Sir Julian Corbett's deductions from the facts and the coaclusions to which the Admiralty have come, but I understand that Sir Julian was precluded from giving references to documents which are still confidential, so that he was unable to document his history in the way which a naval officer would have done. The reader will, therefore, always be left in the dark as to what is the Admiralty's opinion and what is Sir Julian Corbett's opinion. The Naval Staff monographs we are now producing give full references for every statement that we make. We give in appendices important telegrams and important documents, so that a monograph produced by the Training and Staff Duties Division is practically a chapter of the Naval Staff History, excegt of course that it contains no comment. One of the speakers said he did not see why we should have to wait for ten years to know what had happened during the War. The object of the Naval Staff monographs is that a naval officer shall know what happened during the War. Another point he made was that the best authorities on events are the people who took part in them. 'That is very true, but it is not absolutely true. I have this very afternoon consulted an officer who was concerned in a certain operation; in fact I showed him a monugraph which was being prepared on the subject, and he said: "On page 29, line 6 and so on, what is stated is quite wrong." I said : "I am very sorry, but they are your own words," and I actually produced his own report in which he had made the statement that I had put down. He was the officer who conducted the operation; he was the officer who had sent in the report; but seven years afterwards he had forgotten all about it and actually contradicted what was said in the Nayal Staff monograph. I believe that is quite a common occurrence with historians. The actors in the drama which you are portraying have forgotten thcir parts, and they are very apt to put down to somebody else the part which they themsclves played, or conversely-not, of course, intentionally. I believe it is the custom in the Navy-it was when I was at sea some years agofor officers to go into the wardroom and discuss all sorts of things, and finally they arrive at what is called a composite opinion. Someone begins by expressing a very definite opinion; he is rudely contradicted by the gunnery officer; then the torpedo officer ejects a certain amount of poisonous gas; and finally an opinion is arrived at which is distinctly a composite one. But we historians have to go back to the actual reports of the pcople who carried out the operations and wrote down at the time what happened. It is my own experience that the very best source of information (I say it with all due deference) is not always the admiral's despatch. We go back farther than that; we go back to the signal books and to the logs of the ships. If we want to know whether a ship nas steering northeast or. south-west we do not take the admiral's word for it, but the log. If we wiant to know whether a signal was made at 9 o'clock or so o'clock, we do not take the admiral's nord for it; we look and see what the signal boy says. The signalman wrote it down at the time and he is sure to know the truth. That means that an enormous amount of investigation is required and a colossal library of books. If you want to write the history of an action you have no idea of the amount of information that has to be studied. Take a battle like that of the Dogger Bank; the logs themselves would make a pile as high as this room. Both the logs and the signal books have to be scrutinized and compared the one with the other. Each one, of course, will differ from all the others, especially the signal logs, as you may imagine, and we have to piece them together, compare them in parallel columns and finally come to some definite conclusion as to the signal that was made, what time it was made, what time it was received and when it was acted upon. All those things come out in the study of the logs. So that the production of a history is going to take a very long time, and if we aro going to wait ten years before we begin we shall be very much in arrears when the next 
war comes on. It scems to mc, therefore, the best thing to do is to start at once doing the best.you can. We can now arrive at a definite narrative of what we ourselves did and the reason why we did it. The decision whether we were right in whitt we did or whrther our ideas as to what the enemy nere doing were right or not we shall liave to defer until they themselves tell us what they were doing and why they were doing it. 'The first part of the Naval Staff History, that is the narrative of events, can be begun at once, and if there was sufficient staff to do it it would be done. I was talking recently to a member of the Historical Section of the Japanese Navy. That Section has been in cxistence for several years, and its job is to writc history and write it quiclily-to produce it for immediate use. Their Staff History of the Russo-Japanese War was written and complete in I30 volumes in I forget how many years after the war-perhaps three or four years. There is one other point which has not been touched upon in connection with the Writing of Staff Histuries to which I should like to refer. Captain Dewar mentioned the connection between history and business. I would like to give an illustration of that from the Japanese side. The Japanese Historical Section was a definite part of the Naval Staff, and I was informed by a member of that Section that his work of producing the history was very much impeded because the Naval Staff would keep on asking his opinion about future operations. They repeatedly asked whether such and such operations had bcen suitable in the past and how they had been conducted. He thought that was a great obstruction to the work of compiling a history, but it secms to me rather a feather in the cap of the Historical Section that the staff which were conducting operations and which were drawing up orders actually consulted the Historical Section as to what effect those orders would have. 'That was never done so far as I know in our Navy, but in the Japancse Navy it is the practice. Whether it is a practice we should adopt or not I must leave to higher authorities to decide.

Captain Alfred Dew,ik, in reply: I do not think there are any very important points to which I have to reply. All the spenkers secm to agree that history is very important. I do, however, disagrce with the suggested ten years' burial, because in that time papers disappear and logs go away. I think ten years is much too long. Of course it is necessary to kecp many things confidential, and the Naval Staff History would be confidential. Still you can very much overdo secrecy, and it was very much overdone during the W'ar. I feel sure that Admiral Sturdec has something very interesting and instructive to say to us, so I will not occupy your time any longer.

The Cimirgan (Admiral Sik F. C. Sturdfe, Bart., G.C.B., K.C.M.G., C.V.O., LL.D.): Ladies and Gentlemen, I rise to propose a hearty vote of thanks to Captain Dewar for his intercsting lecture and for the interesting discussion it has evoked. Probably you expect a few remarks from me. I should like to say that, as 500n as the War commenced the Naval Historical Section in this country was started, on $4^{\text {th }}$ August, 1914, by Sir IVilliam Slade and Sir Julian Corbett. All papers and records were sent to them. What happened after four or five months I do not know, as I had left, but I do know that a start was made as soon as the War commenced. I am absolutely of opinion that we ought to have the records of what happened at once. We want the Staff Ilistory to-day. As InstructorCommander Tuck mentioned, it will not be final, but it will show what the admirals and the captains did at the time, and on what information they acted. When we get the other side of the case it can be corrected and brought up to date. I am sure it is a mistake to wait for years until a history is produced. I do not personally agree that criticism of an action is contrary to discipline. The facts are therc, and it is for the staff (I am not talking of the public) to consider 
those facts and sece whether they could have done better with the information which the admiral who was in charge of the operations possessed at the time. I, therefore, think it is very inportant that this history should be published for stafi work as soon as possible, otherwise the experience will be lost. Of course it should be confidential. IVith - regard to the next point, I do not think we have been careful enough in keeping our records in the ships. We may not have been carcful enough in keeping the cloclis correct by Greenwich time. No doubt when guns are fired the chart house clock alters, and that is one of the reasons why the times recorded are not always the same. I am in absolute agreement that you cannot always trust to the admiral's memory. He is thinking of many more important things than history, but he has someone who writes down the facts, viz., the signalman and the recording officer. I can, therefore, quite understand that admirals do not remember the exact details of what occurred. I once found myself in an action doing a figure of eight, which 1 had not realized at the time, but the purpose in view was effected, which was the principal thing. I think the lecturer was perbaps a little hard when he said that the people concerned did not know the facts during the War. Summaries were made, I presume, at the Admiralty, and were considered, besides very good charts with regard to the German submarines and aircraft, and were issued to the admirals. I do not think you can expect every oflicer in the ship to be given these details, neither do I think it necessary. It is the officers who are controlling events who want to know them. It is, of course, very interesting to know facts, but I do not think it would have been the least bit of use for us to linow in the North Sea what was happening in Mesopotamia. I think, however, the Admiralty ought to have a summary made of what was happening in Mesopotamia in order that they might know what would happen if, for instance, they sent an expedition to the IVhite Sea or anywhere else. It is valuable experience and cnables officers to get the facts ready for the next event. In my opinion we want, for the purpose of training officers, to know as much as possible to-day why certain things were done. I do not think you can train a naval war staff if you do not give them this information. We do not want to train them on information a hundred years old. Opinions have now to be formed on very vital questions as to the future policy of the Navy, the building policy of the Navy, and it can best come through the staff. That is how Moltke trained the generals for the war of $18 \% 0$, and I hope the permanent training in the Navy will be carricd out in that way. It is very important that all the facts should be known as soon as possible in order that they may be digested, but it is impossible to come to a final conclusion until we obtain the other side of the case. When that happens-in ten, or it may be thirty, years' time-then the two can be brought together. What happened at Trafalgar was not known for about 100 ycars. What we want now are the facts, what the decisions $u$ ere, the action that was taken, what the ofticers did, and so on.

I propose a hearty vote of thanks to the lecturer for the interesting way in which he dealt with the subject. I hope it will malse us take a greater interest in it in future, so that events may be recorded in order that we may know exactly what we have to do if the war which I heard mentioned happens within the next ten years.

The resolution of thanks was then put and carricd by acclamation.

Coloner. B. C. Grezn: Ladies and Gentlemen, I am sure you would not like the meeting to conclude without according a very hearty vote of thanks to Admiral Sturdee for taking the Chair this evening. At some meetings the Chairmen are merely figure-heads, but de always have at the meetings in our lecture hall Chairmen who not only take the greatest interest in the lecture itself but 
act as judges and sum up the case for and against. I have attended many lectures here, and I find that we always gain a great deal of valuable information from the Chairmen. Some of the audience hold the opinion of the lecturer; some of them, as has occurred to-night, differ on some point or other from the lecturer; but in our Chairman we alnays have an impartial man who sums up for and against and enlightens us in general on the subject. Our Chairman to-night has put before us what he thinks-should be done, and I for one absolutely endorse his vieu's. We have all very much enjoyed the lecture, and I am sure we have equally enjoyed the comments which have been made not only by the speakers but by the Chairman. Ladies and Gentlemen, I ask you to accord a very hearty vote of thanks to Admiral Sturdee for presiding this evening.

The resolution of thanks was carried by acclamation, and the meeting terminated. 